\title{
Perspectives of the oil potential of the Bazhenov formation within the Kogalym top of the Surgut arch
}

\author{
D.A. Spiridonov \\ Geologist, OOO LUKOIL-Engineering, Kogalym NIPIneft, Tyumen, Russia
}

\begin{abstract}
Based on the analysis of the geological structure of the territory, mineral composition of rocks and bedding conditions, the most promising areas for the development of the Bazhenov formation were localized.
\end{abstract}

\section{Introduction}

Constant interest in the development of bituminous rocks of the Bazhenov horizon contributes to the active scientific study of the deposits. The Bazhenov formation is one of the most fully studied objects of the oil and gas industry in the Russian Federation. The study of the formation rocks began in the USSR in the 1950s with the discovery of the formation's oil-bearing capacity at the Salym field. The formation was studied by prominent Soviet and Russian scientists: A.E. Kontorovich, A.A. Trofimuk, O.K. Bazhenova, I. I. Nesterov, T. V. Dorofeyeva, S. G. Neruchev, E. A. Predtechenskaya, Yu. Braduchan, F.G. Gurari, and many others. However, despite half a century of studying, the production of oil inflows from the formation remains unpredictable. A successful development of such complex objects is impossible without complete and qualitative geological and geophysical information about the deposits. This article describes the geological composition of the Bazhenov formation within the Surgut and Nizhnevartovsk arch and the North Vartov mega-terrace of the West Siberian Plate. Production activities in the studied territory are carried out byLCC LUKOIL-Western Siberia.

\section{Tectonic structure of the territory}

According to the tectonic map of the central part of the West Siberian Plate edited by V.I. Spilman, L.L. Podsosova, N.I. Zmanovsky (1998), the studied territory is confined to major positive elements of order I - the Surgut arch, the Nizhnevartovsk arch, the North Vartov mega-terrace. Within the boundaries of the Surgut arch, the element of order II is the Kogalymtop. The the east of the Surgut arch with numerous structures of order is the North Vartov s. The Nizhnevartov arch is identified to the southeast of the arch (Fig. 1). 


\section{Geological structure of thebazhenov formation}

The Bazhenov formation is composed of bituminous silicious carbonate-clay deposits. The rocks are black with a brownish shade of different intensity, with flat, up to the shell, fractures, and a multi-plate structure. Layers of silicon and limestone argillites up to radiolarites and clay-limestone, sometimes dolomitic, are frequent. A distinctive feature of the Bazhenov formation is the high organic matter content, sometimes reaching $20 \%$ or even more.

According to the zoning of the Bazhenov horizon according to the types of sections performed by the specialists of V.I. Shpilman Research and Analytical Centre for the Rational Use of the Subsoil, two types of sections are identified in the studied territory: Salym type section and Nizhnevartovsk section [1]. Salym type of section in its turn is divided into two zones: the 1st zone is defined in the southwestern part of the territory; the 2nd zone occupies most of the North Vartov mega-terrace and the Nizhnevartov arch. The southeastern part belongs to the Nizhnevartovsk type of section (Fig. 2).

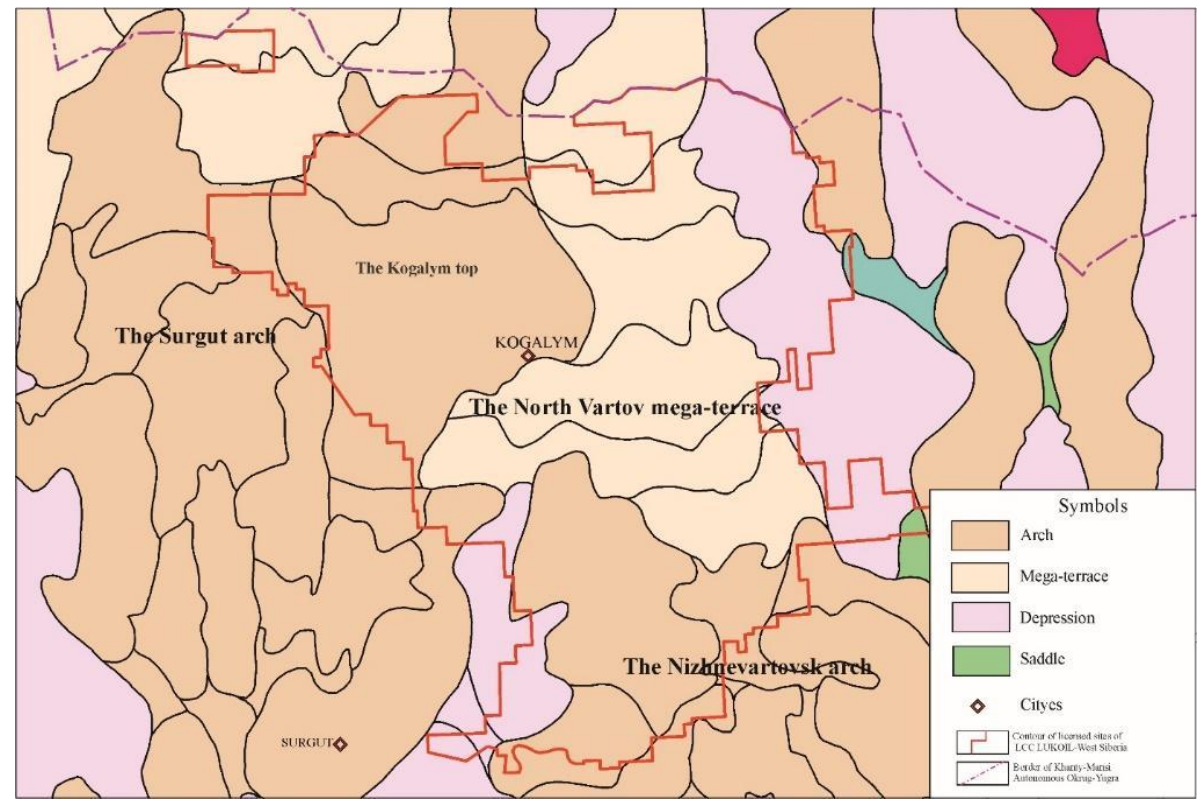

Fig. 1. The tectonic map of the central part of the West Siberian Plate edited by V.I. Spilman, L.L. Podsosova, N.I. Zmanovsky (1998). 


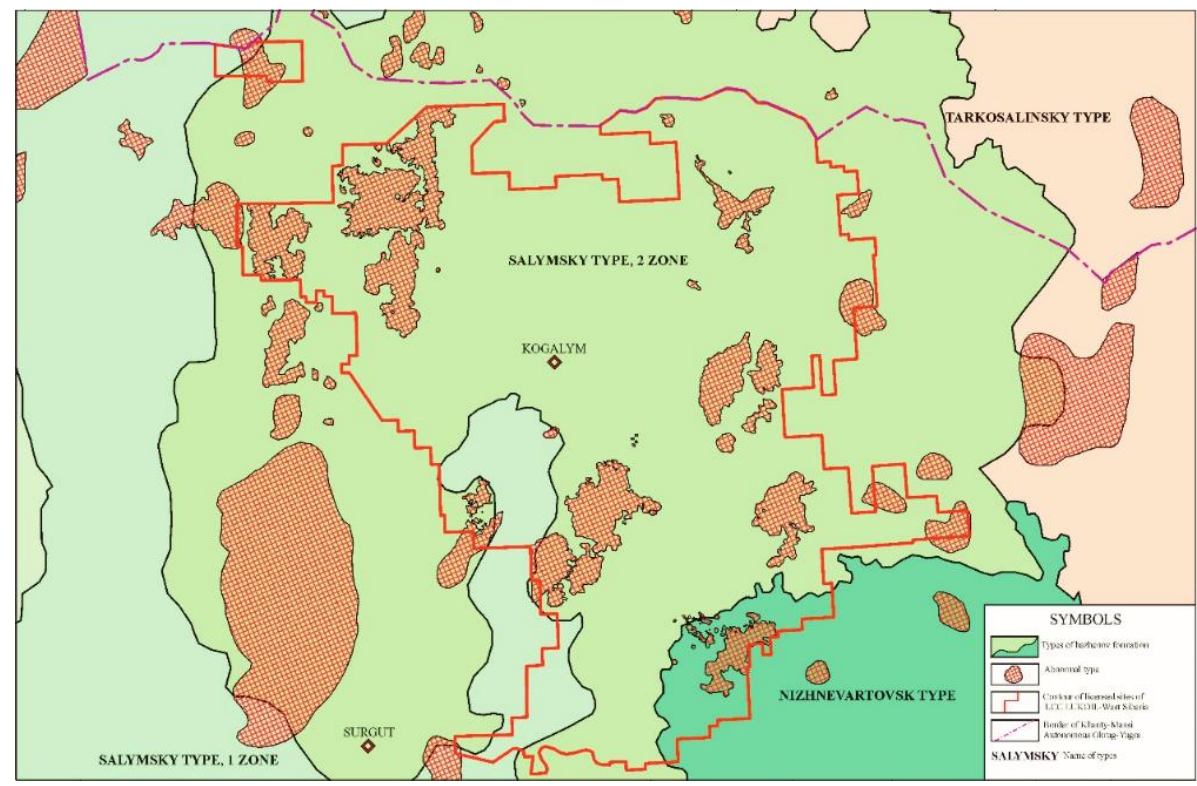

Fig. 2. Types of the Bazhenov formation sections according to V.I. Shpilman Research and Analytical Centre for the Rational Use of the Subsoil with supplemented ASB contours.

A distinctive feature of the territory where LUKOIL-Western Siberia operates in the Central $\mathrm{Ob}$ River Region is the presence of areas with an anomalous section of the Bazhenov formation (ASB) (Fig. 2). Zones of anomalous sections are represented by areas, in which the bituminous Bazhenov deposits lie considerably above their normal stratigraphic position [2] and are delaminated with sandy and clay rocks, which do not differ from the overlying Achim deposits in appearance and terms of the composition of deposits. The development of landslide and fluid textures and cracks is characteristic of the ASB forming rocks. Sharp-edged and extended (evidence of a lack of active transportation) debris of bituminous rocks of all shapes and sizes commonly occurs in sandy rocks. The clays have cracks of strange shape, neptunic dikes made by sand material, in some interlayersrocks "stand on head." Contacts between lithological varieties are torn, sharp, without gradual change of grain; numerous contacts are representing sliding mirrors with characteristic striation. The author, based on the analysis of logs and core material, identified 2 types of ASB. The first type is characterized by the complete displacement of the original rocks of the Bazhenov formation and the maximum thickness of the ASB. The second type is characterized by the maximum preservation of the thickness of the undisturbed section of the Bazhenov formation.

The thickness of deposits is an important criterion for assessing the prospects of the Bazhenov formation. The larger thickness of the formation, the larger the volume of oil it could generate, and hence the higher the prospects for oil availability. A significant thickness will better restrain the height of the hydraulic fracturing crack and open more intervals with potential reservoir layers. The critical value of the thickness at which the formation can be potentially productive was determined by F. G. Gurari et al. and assumed to be $25 \mathrm{~m}$ [3].

During the research, a thickness map of the normal section of the Bazhenov formation was created (Fig. 3). The map was composed based on the author's breakdowns of well log data for more than 9800 wells of LUKOIL-Western Siberia and adjacent fields of thirdparty entities. The upper boundary of the formation was bounced off by increasing values of gamma-ray and resistivity logs, the lower boundary was bounced off by abnormally 
increasing values of induction logs, which characterize the rocks of the Georgievskaya Formation enriched with glauconite. No seismic data were used in the interpretation of the $\log$ data. The average thickness of deposits is $23 \mathrm{~m}$, the minimum thicknesses are confined to the zones of the "anomalous section" of the Bazhenov formation. Several zones of increased thickness are identified in the studied area, in which the thickness of deposits exceeds $25 \mathrm{~m}$. The zones are confined to the Kogalym top of the Surgut arch, the Yarsomov trough, and the North Vartov mega-terrace. The area of increased thicknesses within the Kogalym top is characterized by the stretched upper boundary of deposits, which is typical for deposits of the 1st zone of the Salym-type section, which also includes the area of increased thicknesses within the Yarsomov trough.

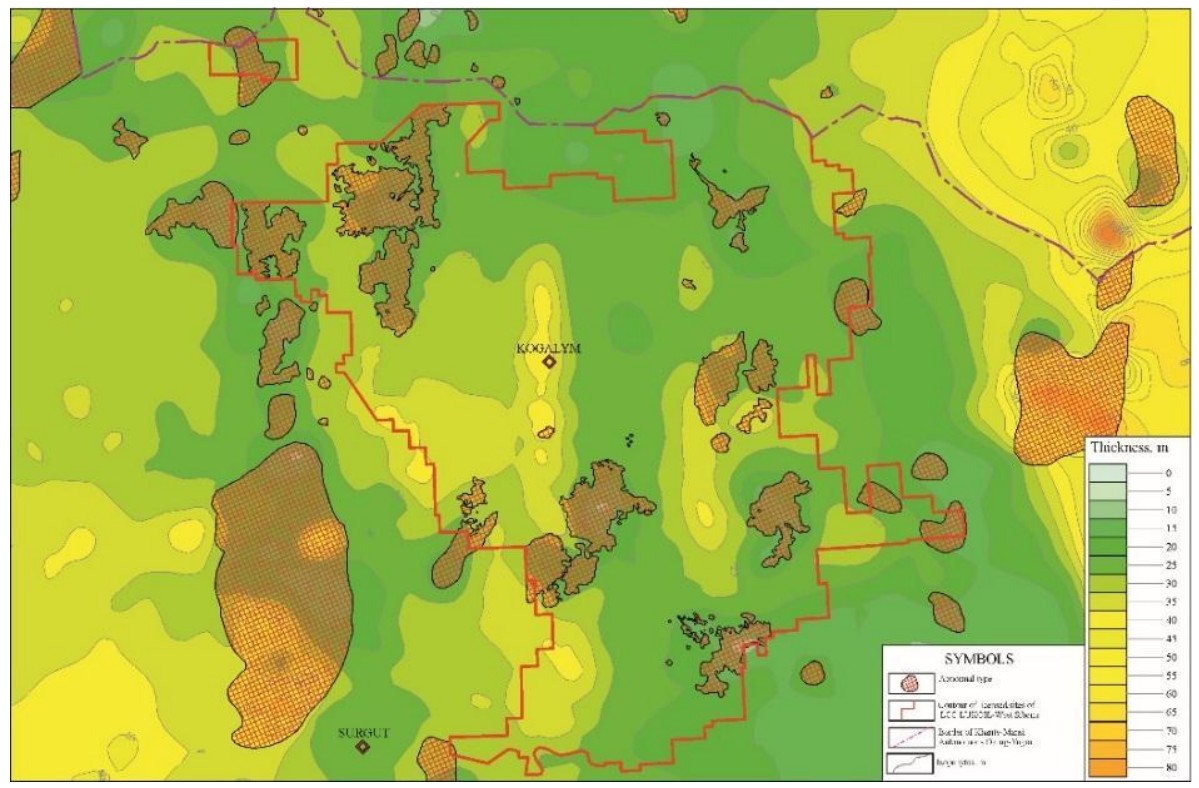

Fig. 3. Thickness map of a normal section of the Bazhenov formation with ASB contours.

Therefore, the area of the 1st zone of the Salym-type section as identified by the experts of V.I. Shpilman Research and Analytical Centre for the Rational Use of the Subsoil should be adjusted and it should include the territory of the Kogalym top of the Surgut arch. The area of the increased thicknesses identified within the North Vartov mega-terrace is characterized by an increased number of interlayers of carbonate rocks in the section. This area can be attributed to a special subtype of the Salym-type section. As a result of the work carried out, a diagram of the refined boundaries of the section types of the Bazhenov formation was plotted. 


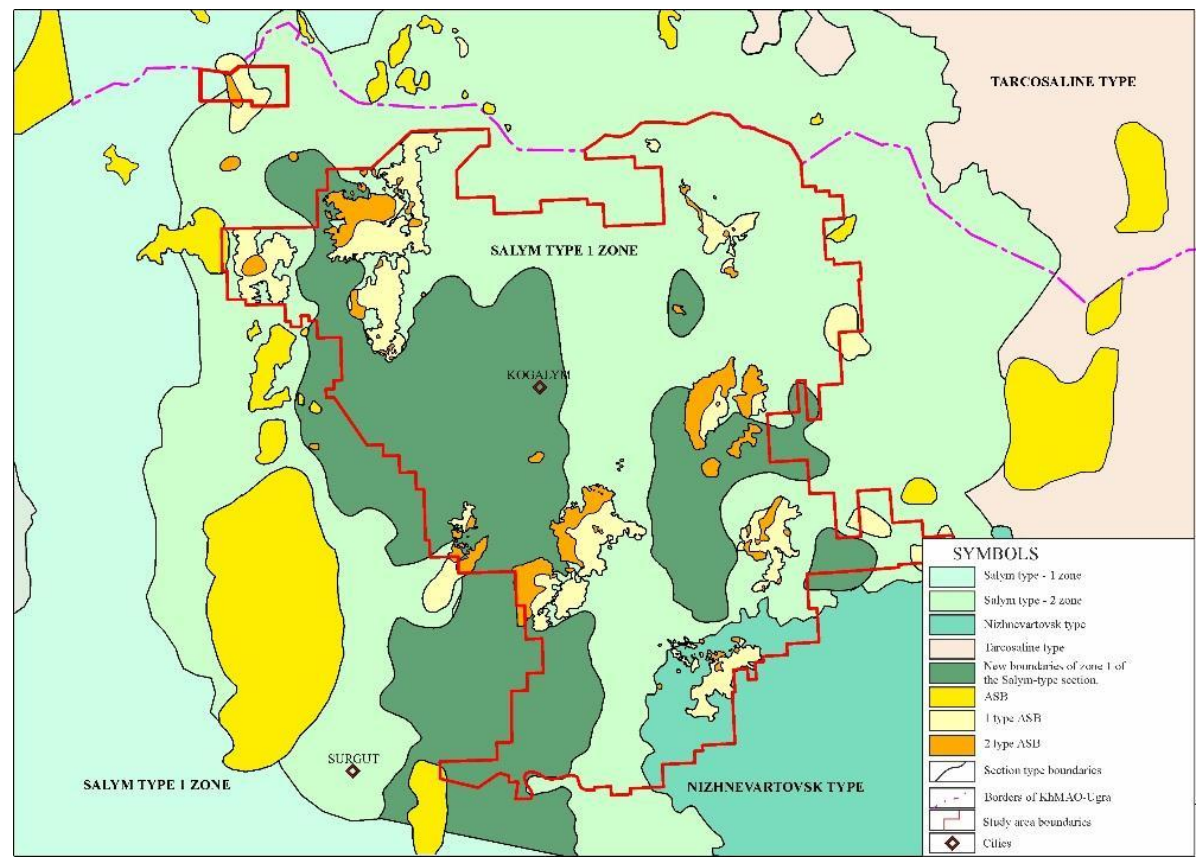

Fig. 4. Scheme of the refined boundaries of the types of the section of the Bazhenov formation

\section{Compositional analyses of rocks}

Knowledge of the mineral and geochemical structure of rocks of the Bazhenov formation is important for the identification of litho types of rocks, with which the improved permeability and porosity are connected. Variations of the composition of the main components of the formation by section may influence the efficiency of hydraulic fracturing. Generally, quartz-rich rocks are more fragile and they enable better wells completion. Rocks enriched with clay minerals are more plastic and, therefore, reduce the efficiency of hydraulic fracturing.

Based on data of X-ray diffraction study of 952 core samples from 150 wells, the mineral composition of deposits of the formation was studied. The main component of the rocks is silicon oxide, with an average content of $46 \%$. Carbonate minerals content is high: calcite content averages $20.17 \%$; dolomite content averages $24.66 \%$; siderite content averages $3.72 \%$. The average content of potassium feldspars is $5 \%$; plagioclases content averages $8.2 \%$. Pyrite content is high; it averages $7.67 \%$. Clay minerals: kaolinite content averages $5.15 \%$; chlorite content averages $3.41 \%$; hydromica content averages $7.54 \%$. Upon evaluation of the obtained results, it is possible to assume that deposits of the Bazhenov formation of the studied region, thanks to the high content of silicon dioxide and the minimum content of clay minerals, have a favorable mineral composition for hydraulic fracturing.

Many authors emphasize the importance of hydromica prevalence as a part of clay minerals of the Bazhenov shale. It is considered that hydromicatization is an obligatory stage of transformation of formation rocks, without which emergence of the interconnected pore system and the improved collection properties is impossible. After completing the main stage of hydromicatization, bitumoids are transformed into a state, which is not connected with the rock, and after that conditions emerge for receiving oil inflows in wells [4]. Upon evaluation of the results of the X-ray diffraction analysis, it is possible to 
conclude that in deposits of the studied area hydromica prevails slightly over kaolinite and chlorite, and hydromica content increases from the top to the bottom of deposits.

\section{Potential oil reservoirs}

The first commercial oil inflows from the Bazhenov formation outlined the main problems, i.e., identification and forecasting of reservoirs. Currently, most researchers believe that the main inflow intervals in the Bazhenov formation are carbonate rocks - limestones and dolomites, re-developed by radiolarites. $[5,6,7]$. In the wells, which tapped the Bazhenov deposits with coring, carbonate rocks occur mainly in the lower part of the section. In carbonates, direct signs of hydrocarbons are observed: oil stainings, a blue glow in UFlight, and oil odor. Carbonates are well identified on well logging data and are characterized by a relative minimum in gamma logging, a relative maximum in neutron logging, and a maximum in lateral logging [8]. The author has identified a carbonate reservoir in 7800 wells on the basis of well logging data and macroscopic description of core samples from 132 wells. The carbonate interlayer in the studied subsoil area is developed almost everywhere and is absent only in ASB zones. It is presented by one or, less often, by several interlayers; the average layer thickness is $0.88 \mathrm{~m}$. The minimum thicknesses are mainly confined to Nizhnevartovsk arch and the North Vartov megaterrace, the maximum thickness of potential reservoirs are developed within the boundaries of the Kogalym top of the Surgut arch.

\section{Localization of potentially productive zones}

For localization of potentially productive zones within the license areas of LUKOIL-West Siberia in the Central Ob River Region, analysis of a geological composition, mode of occurrence, thickness of deposits, organic matters content was made, and results of tests of 623 wells, which tapped Bazhenov deposits within Khanty-Mansi Autonomous District were analyzed. Test results were taken from research reports, scientific and technical literature, and well files.

Several authors consider formation temperature as the only indicator with a distinct relationship with the formation oil-bearing capacity. The Earth's thermal field has the main impact on catagenesis processes and oil and gas formation in sedimentary and predetermines strata and predetermines distribution of heat flows, temperatures, and geothermal gradients in the Earth's crust [8]. Formation temperatures above $95-100^{\circ} \mathrm{C}$ are considered promising for receiving oil inflows from the Bazhenov formation. Wells with inflows are located in a wide range of formation temperatures - from 75 to $130^{\circ} \mathrm{C}$; at temperatures over $100^{\circ} \mathrm{C}$, there is a tendency for flowrates to increase. Within the studied area, formation temperatures of upper Jurrasic deposits over $90^{\circ} \mathrm{C}$ are detected in the Surgut arch, the North Vartov mega-terrace, the Pyakupurmegatrough, and in the northern part of the Nizhnevartov arch. Most parts of wells with oil inflows from the formation deposits are confined to the Kogalym top. Comparing values of paleotemperatures and results of tests, it can be noted that the majority of wells with oil inflows are concentrated in the narrow range of paleotemperatures of $125-150^{\circ} \mathrm{C}$. In the studied area a paleotemperature over $125^{\circ} \mathrm{C}$ as been identified in the north and coincides with the maximum current formation temperatures.

Formation thickness is of high importance when considering generated volumes of hydrocarbon matters. The greater the thickness of the deposits, the greater the volume of formation suites could generate, the higher the density of reserves and, accordingly, the higher the prospects for oil potential. Wells, in which oil inflows are received, are concentrated in the range of thickness from 15 to $40 \mathrm{~m}$. The maximum flow rates are in the 
range of 25-40 m. The thickness of deposits over $25 \mathrm{~m}$ has been identified in the huge territory and is confined to the Salym-type section of the Bazhenov horizon. Within the boundaries of the studied site, the area of maximum thickness has been identified within the Kogalym top of the Surgut arch. In the eastern part, some local zones with increased thickness have been identified. In the western area, wells with oil inflows from deposits of a normal section of the formation are concentrated. In the eastern part, commercial oil inflows were obtained in one well only.

A favorable factor is the high content of $\mathrm{OM}$, which can generate a greater amount of hydrocarbons. Comparing the results of tests and the average content of organic matter, it may be noted that the minimum content of organic matter at which inflow can be obtained is limited to $5 \%$. The maximum flow rates are limited to $10 \%$. Perhaps, it is because wells are situated in "hotter" subsoil sites. Oil generation in high-temperature sites is more intensive, and the number of organic matters reduced faster and in a bigger volume than in low-temperature sites. The average organic matter content in the studied area varies from 6 to $10 \%$. As a result, maps of the prospects of the selected criteria were built and the territory was ranked according to the degree of prospects (Fig. 5). Within the boundaries of LUKOIL-Western Siberia's activities, the maximum prospects are associated with the western part, with the Kogalym peak of the Surgut arch.
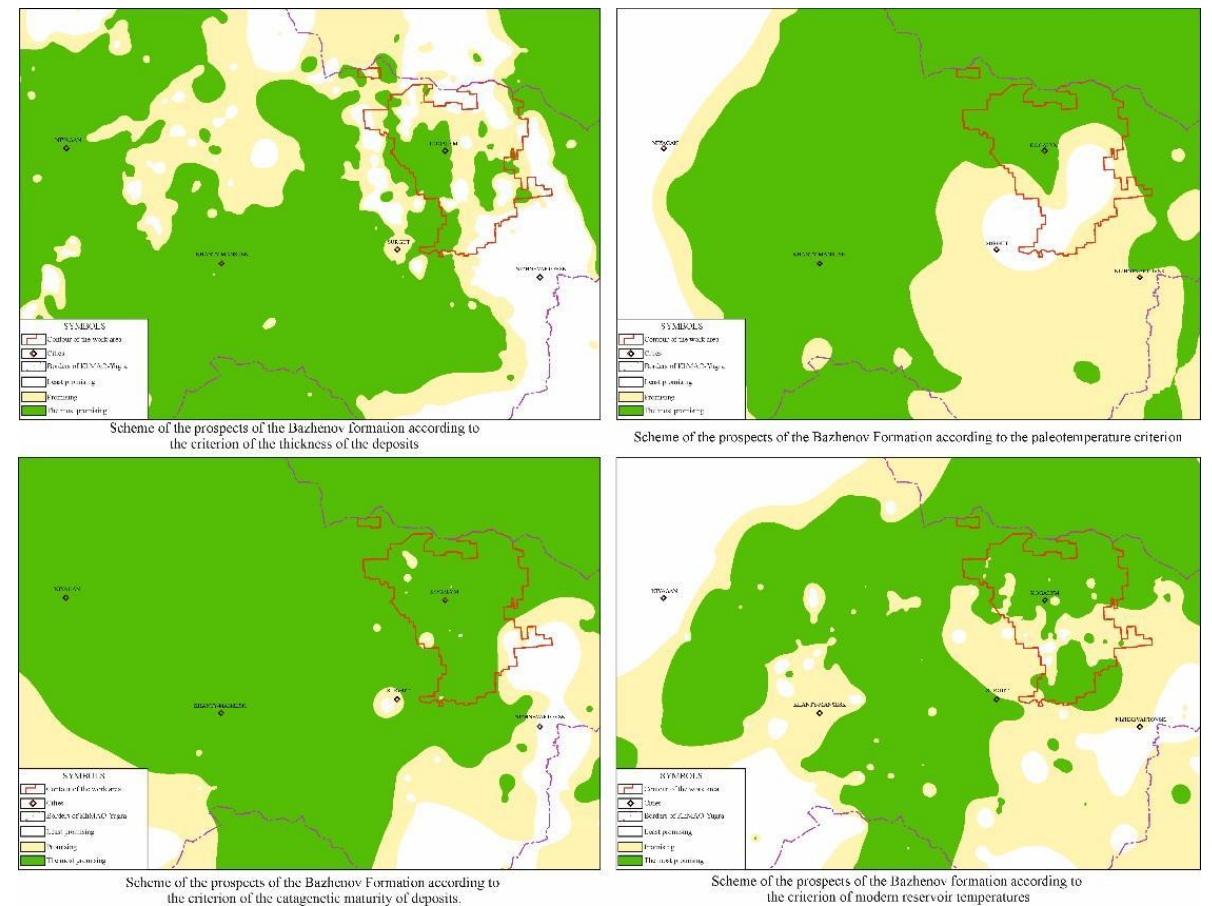

Fig. 5. Schemes of the Bazhenov formation prospects.

\section{Conclusions}

Clarification of the geological structure makes it possible to attribute the Kogalym peak to the 1 st zone of the salym-type of section. Within the boundaries of the kogalym peak, the thickness of carbonate reservoirs increases. The considered regional geological and 
geochemical criteria correspond to the kogalym summit of the surgut arch as an optimal zone for the development of deposits of the bazhenov formation. Within the roof, modern reservoir temperatures reach $90-100^{\circ} \mathrm{c}$, paleotemperature starts from $125^{\circ} \mathrm{c}$, sediment thickness varies from 25 to $40 \mathrm{~m}$, average organic matter content is above $5 \%$. Within the kogalym top, the maximum oil inflows are obtained from the deposits of the normal section of the bazhenov formation.

\section{References}

1. Mukher A.G., Kulagina, S.F., Pakhomova, E.A., Zonation of the Bazhenov horizon by types of sections in the territory of KhMAO-Yugra and adjacent areas. Ways of realization of oil and gas capacity of the Khanty-Mansi Autonomous District-Yugra; Materials of 20th Scientific and Practical Conference. Khanty-Mansiysk1, 163-194 (2017).

2. Nezhdanov A.A., Kulagin S. F., Kornev F.A., Hafizov F.Z.Oil and Gas Anomalous sections of the Bazhenov formation: a look after half a century since detection. 6 (2017)

3. BraduchanYu.V.,Golbert A.V., Gurari F.G., Zaharov V.A., Bazhenovsky horizon in the Western Siberia (stratigrafija, paleogeografija, jekosistema, neftenosnost'). Novosibirsk, 217 (1986).

4. Dorofeyeva, T.V. (eds.). Oil reservoirs of the Bazhenov formation in Western Siberia. Leningrad: Subsoil, 131 (1983).

5. Alekseyev, A.D., Natural oil reservoirs in deposits of the Bazhenov formation in the west of the Latitudinal Ob River Region: candidate thesis in geological and mineralogical sciences: 25.00.12 Moscow, 186 (2009).

6. Nemova, V.D., Koloskov, V.N., Pokrovsky, B.G., Formation of carbonatized reservoirs in argillaceous and siliceous deposits of the Bazhenov horizon in the west of Latitudinal Ob River Region. Sub-soil exploration and protection 12 (2011).

7. Usmanov, I.Sh.,Trofimova E.N., Dyakina, A.V., Karlov, A.M., Oil Economy Oilsaturated limestones of the Bazhenov formation of the Surgut District.12 (2005).

8. Sokolov B.A. Evolutionary and dynamic criteria for evaluation of oil-and-gas content of subsoil. Moscow: Subsoil, 168(1984). 